\title{
PSEUDOANEURISMA ARTERI FEMORALIS
}

\author{
Ester O. V. Mewengkang \\ Reginald L. Lefrandt
}

\author{
Divisi Kardiologi Bagian Ilmu Penyakit Dalam \\ Fakultas Kedokteran Universitas Sam Ratulangi Manado \\ Email: ester.med92@gmail.com
}

\begin{abstract}
Pseudoaneurysm is an accumulation of blood extravascularly in a space or cavity related to an artery, associated with disruptions of vessel layers. We reported a 51-year-old male with a pseuudoaneurysm of the left femoral artery. A lump in the left inguinal region occured due to a instrument wound during his fifth hemodialysis. The $6 \times 5 \mathrm{~cm}$-sized lump was hard, fixed, and painful in palpation, and had a bluish red center. A bruit was detected on auscultation. Diagnosis was based on the occurence of the lump in the inguinal region after the fifth hemodyalisis, a bruit on the lump, and a USG doppler examination that showed an aneurysm of the left femoral artery. The patient was operated on, and a pseudoaneurysm of the left femoral artery was found during the exploration. On day 36, the patient's physical condition was improved and he was permitted to leave the hospital. From the pseudoaneurysm aspect, the prognosis of this patient was good, but in general the prognosis was dubia ad malam.
\end{abstract}

Key words: pseudoaneurysm, femoral artery

\begin{abstract}
Abstrak: Pseudoaneurisma atau aneurisma palsu adalah akumulasi darah ekstravaskuler dalam suatu rongga yang terhubung dengan arteri, disertai disrupsi lapisan pembuluh darah. Kami melaporkan kasus seorang laki-laki berusia 51 tahun dengan pseudoaneurisma arteri femoralis. Diagnosis ditegakkan berdasarkan gejala dan tanda klinis dimana ditemukan benjolan di lipat paha kiri yang timbul akibat tusukan pada saat menjalani hemodialis kelima, pemeriksaan fisik adanya bruit pada benjolan, dan USG doppler memperlihatkan adanya aneurisma arteri femoralis kiri. Pasien dilakukan pembedahan, dan pada saat eksplorasi ditemukan adanya pseudoaneurisma arteri femoralis kiri. Setelah perawatan hari ke-36, keadaan pasien membaik dan bisa dipulangkan. Prognosis pseudoaneurisma pada pasien ini baik, tetapi secara keseluruhan dubia ad malam.
\end{abstract}

Kata kunci: pseudoaneurisma, ateri femoralis

Pseudoaneurisma atau aneurisma palsu adalah akumulasi darah ekstravaskuler dalam suatu rongga yang terhubung dengan arteri yang disertai disrupsi lapisan pembuluh darah. ${ }^{1}$ Pseudoaneurisma arteri femoralis (PAF) merupakan masalah pada regio inguinal (selangkangan) akibat komplikasi luka tusuk, yang biasanya sekunder akibat tindakan diagnostik dan terapeutik seperti kateterisasi jantung, biopsi renal perkutan, dan hemodialisis. ${ }^{2-4}$

Pseudoaneurisma arteri femoralis ter- jadi pada 0,1-0,2\% akibat tindakan diagnostik angiogram dan $0,8-2,2 \%$ akibat tindakan invasif untuk prosedur kardiovaskular. ${ }^{5}$ Di Amerika Serikat, kateterisasi jantung dilakukan kira-kira lebih dari satu juta per tahun, tetapi kejadian PAF pasca prosedur relatif jarang. Insiden PAF akhirakhir ini meningkat seiring dengan peningkatan penggunaaan yang lebih sering dari agen trombolitik, antiplatelet, dan antikoagulan, serta penggunaaan kanul berukuran besar pada prosedur invasif. ${ }^{2,3}$ 
Dari anamnesis kasus PAF biasanya didapatkan benjolan yang disertai nyeri walaupun seringkali belum nampak tandatanda pada awal terbentuknya dan sering salah didiagnosis atau bahkan diabaikan. ${ }^{6}$ Tanda-tanda adanya PAF dalam pemeriksaan fisik antara lain pada palpasi didapatkan massa yang berdenyut, adanya getaran (thrill), dan pada auskultasi dapat didengar adanya bruit. Pencitraan penting untuk menunjang diagnosis yaitu berupa ultrasonografi (USG) doppler, computed tomographic (CT) angiografi, magnetik resonansi (MR) angiografi, dan angiografi konvensional. Diagnosis PAF ditegakkan berdasarkan gejala klinis, pemeriksaan fisik, dan pencitraan. $^{7,8}$

Penanganan PAF tergantung pada ukurannya, bisa secara medikamentosa atau pembedahan. PAF yang berukuran $<2 \mathrm{~cm}$ tidak memerlukan pengobatan, sedangkan yang berukuran besar membutuhkan tindakan pembedahan. ${ }^{1,2,7-9}$

Komplikasi pseudoaneurisma yang paling ditakutkan ialah perdarahan. Komplikasi lainnya yang bisa terjadi yaitu trombosis, insufisiensi vaskular bagian distal, neuropati, serta infeksi dan iskemi kulit lokal. ${ }^{10}$

\section{LAPORAN KASUS}

Seorang laki-laki usia 51 tahun, suku Minahasa, masuk rumah sakit Prof Dr RD Kandou Manado pada tanggal 16 Oktober 2011 dengan keluhan utama benjolan di lipat paha. Benjolan timbul sejak kira-kira satu bulan lalu yaitu sejak pasien melakukan hemodialisis yang kelima. Benjolan awalnya kecil, lama kelaman membesar dan disertai nyeri, tidak mengeluarkan cairan, dan teraba lunak sehingga oleh pasien diduga timbunan lemak. Selama timbul benjolan pasien tidak pernah mengeluhkan demam, tetapi sejak satu minggu sebelum masuk rumah sakit pasien merasa panas sumer-sumer. Batuk kadang-kadang dengan lendir putih cair, juga kadang-kadang merasa sesak. Buang air kecil sedikitsedikit dan kadang-kadang terasa nyeri. Buang air besar lancar. Pada riwayat penyakit dahulu didapatkan gangguan ginjal stadium akhir sejak tiga bulan terakhir, tekanan darah tinggi sejak 10 tahun yang lalu, dan peningkatan asam urat sejak dua tahun yang lalu. Riwayat penyakit kencing manis disangkal. Tidak ada riwayat keluarga yang mengalami sakit seperti pasien.

Pada pemeriksaan fisik keadaan umum tampak sakit sedang dengan kesadaran kompos mentis. Tekanan darah 160/100 mmHg; denyut nadi 90 kali permenit, reguler, isi cukup; frekuensi pernafasan 24 kali permenit, suhu badan aksiler $36,8^{\circ}$ Celcius. Konjungtiva tampak anemis, sedangkan sklera tidak tampak ikterik. Pada daerah leher tidak didapatkan pembesaran kelenjar getah bening. Dada tampak simetris baik statis maupun dinamis, fremitus raba kiri dan kanan sama, perkusi sonor kiri dan kanan sama, auskultasi suara pernafasan vesikuler paru-paru kiri dan kanan, tidak ditemukan ronki dan wheezing. Pada inspeksi, iktus kordis tidak tampak, palpasi iktus kordis tidak teraba, perkusi batas kanan jantung di sela iga $\mathrm{V} 1 \mathrm{~cm}$ lateral linea parasternalis kanan, batas kiri jantung sela iga $\mathrm{V} 1 \mathrm{~cm}$ lateral linea miklavikularis kiri, auskultasi denyut jantung 90 kali permenit reguler, suara jantung I dan II normal, tidak ada bising dan gallop. Perut tampak datar, teraba lemas, hati tidak teraba, lien tidak teraba, ballotement ginjal tidak teraba, perkusi timpani, dan bising usus normal. Pada inguinal kiri tampak benjolan ukuran $6 \times 5 \mathrm{~cm}$, bagian tengah warna merah kebiruan, konsistensi keras, terfiksasi, ada nyeri tekan, dan terdengar bruit (Gambar 1). Kedua tungkai bawah dan kaki tidak didapatkan adanya edema.

Pada pemeriksaan laboratorium didapatkan hemoglobin 5,3 g/dL, leukosit $14300 / \mathrm{mm}^{3}$, trombosit $283.000 / \mathrm{mm}^{3}$, gula darah puasa $108 \mathrm{mg} / \mathrm{dL}$, ureum $57 \mathrm{mg} / \mathrm{dL}$, kreatinin $5,8 \mathrm{mg} / \mathrm{dL}$, asam urat 7,0 $\mathrm{mg} / \mathrm{dL}$, kolesterol total $118 \mathrm{mg} / \mathrm{dL}$, trigliserida 118 $\mathrm{mg} / \mathrm{dL}$, SGOT $33 \mathrm{U} / \mathrm{L}$, SGPT $9 \mathrm{U} / \mathrm{L}$, protein total $4,7 \mathrm{~g} / \mathrm{dL}$, albumin $2,0 \mathrm{~g} / \mathrm{dL}$, globulin $2,7 \mathrm{~g} / \mathrm{dL}$, natrium $130 \mathrm{mEq} / \mathrm{L}$, kalium 3,0 mEq/L, klorida $110 \mathrm{mEq} / \mathrm{L}$, urinalisis didapatkan warna kuning keruh, epitel 4-6/lpk, eritrosit 2-4/lpb, lekosit 20-25/lpb, 
nitrit negatif, protein positif, glukosa normal, keton negatif, urobilinogen negatif.
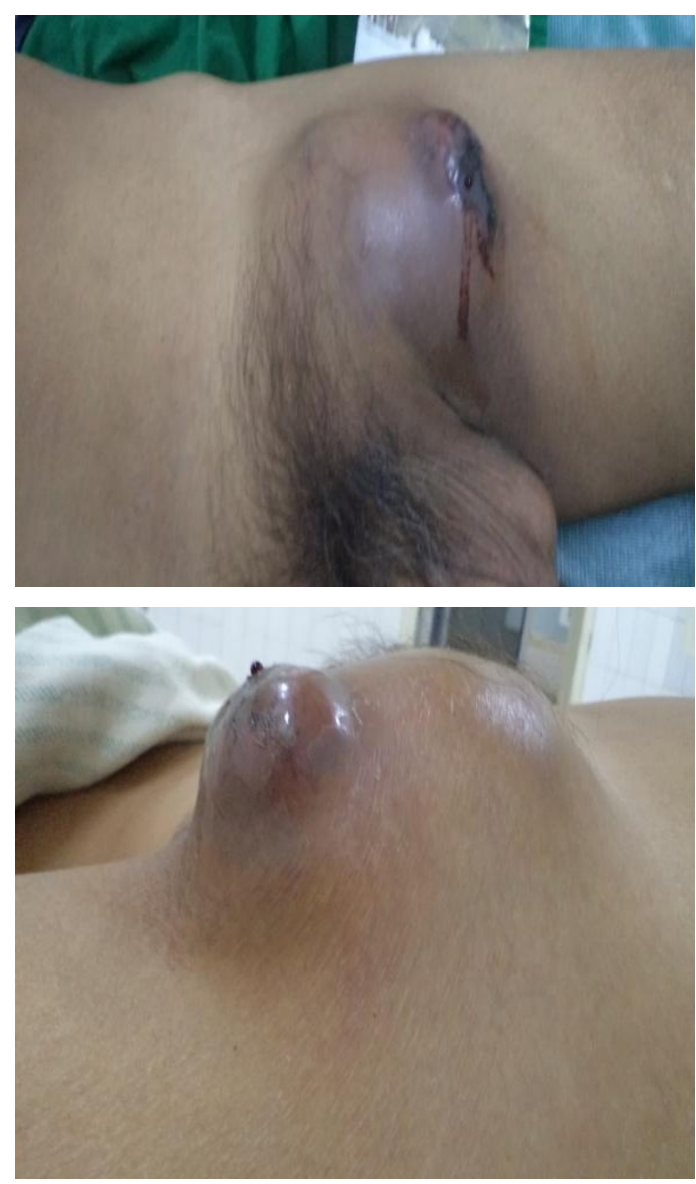

Gambar 1. Benjolan pada area inguinal kiri

Foto toraks didapatkan kardiomegali dan paru dalam batas normal, tidak tampak gambaran pembesaran kelenjar getah bening pada hilus atau mediastinum (Gambar 2).

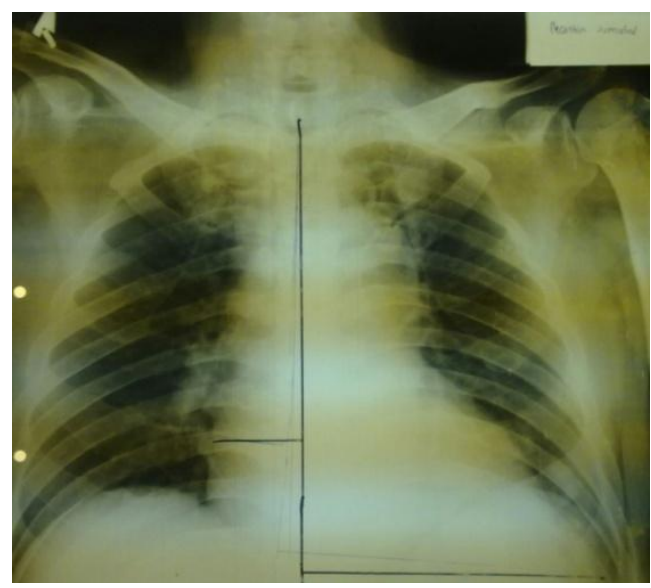

Gambar 2. Foto dada pasien
Hasil rekam jantung didapatkan hipertrofi ventrikel kiri, iskemi lateral. Pada pemeriksaan ultrasonografi (USG) abdomen didapatkan: ukuran hati normal, permukaan regular, tepi agak tumpul, ekostruktur parenkim homogen normal, sistem vaskular vena porta dan vena hepatika tak melebar, sistem bilier intrahepatik dan ekstrahepatik tampak melebar, massa tumor negatif. Kandung empedu normal, tak tampak lesi hiperekoik, batu ataupun dengan acoustic shadow. Dinding tak menebal. Sludge negatif, double layer negatif, massa tumor negatif. Ginjal kanan dan kiri bentuk dan ukuran mengecil. Sistem pelviokalises tak melebar. Batu atau massa tumor negatif. Buli, lien, aorta, usus, prostat tak tampak kelainan. Kesan penyakit ginjal kronik. Hasil USG doppler didapatkan aneurisma arteri femoralis kiri.

Berdasarkan anamnesis, pemeriksaan fisik, dan pemeriksaan laboratorium serta pemeriksaan penunjang maka ditegakkan diagnosis kerja aneurisma arteri femoralis, penyakit ginjal kronik stadium akhir et causa hipertensi nefrosklerosis, anemia pada penyakit ginjal, hipertensi stage 2 , gagal jantung kongestif fungsional I et causa penyakit jantung hipertensi, dan infeksi saluran kemih. Penanganan pasien dengan pemberian infus NaCL $0,9 \%$ selang seling EAS primer 10 tetes per menit, ceftriaxone satu kali dua gram per hari intravena (dilakukan skin test sebelum pemberian), amlodipin $10 \mathrm{mg}$ sekali per hari, valsartan 80 $\mathrm{mg}$ sekali per hari, furosemid $40 \mathrm{mg}$ sekali per hari, transfusi PRC $230 \mathrm{cc}$ pada saat hemodialisis, hemodialisis dua kali per minggu, dan diberikan diet ginjal. Pasien direncanakan untuk dikonsulkan ke bagian bedah vaskuler. Hasil jawaban konsul dari bagian bedah vaskuler yaitu aneurisma arteri femoralis, dan direncanakan untuk dilakukan eksplorasi.

Pada hari perawatan ke 31, benjolan makin membesar dan mengeluarkan darah, kemudian dilakukan eksplorasi dengan segera dan didapatkan pseudoaneurisma arteri femoralis kiri. Pada pembedahan dilakukan eksisi pseudoaneurisma dan ligasi fistula (Gambar 3). 

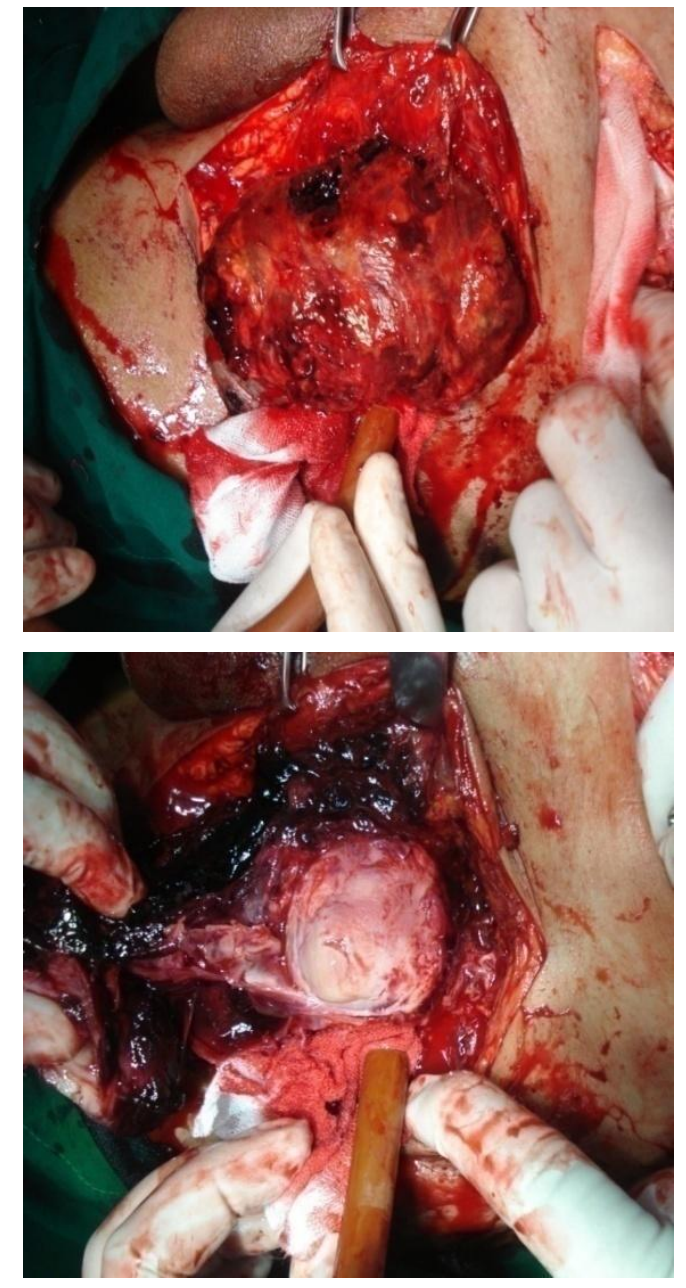

Gambar 3. Ligasi dan pengangkatan pseudoaneurisma pada saat operasi

Pada hari ke-1 setelah operasi (hari perawatan ke-32) didapatkan nyeri pada luka operasi, keadaan umum pasien sedang dengan kesadaran kompos mentis. Tekanan darah 120/80 $\mathrm{mmHg}$, nadi $80 \mathrm{kali} / \mathrm{menit}$, respirasi $20 \mathrm{kali} / \mathrm{menit}$, dan suhu badan $36^{\circ}$ celcius. Pada hari ke-2 setelah operasi, nyeri masih dikeluhkan, keadaan umum pasien sedang dengan kesadaran kompos mentis; tekanan darah $120 / 80 \mathrm{mmHg}$, nadi 78 kali per menit, respirasi 22 kali per menit, dan suhu badan $36,5^{\circ}$ C. Hasil laboratorium hemoglobin $8,7 \mathrm{~g} / \mathrm{dL}$, leukosit $8.400 / \mathrm{mm}^{3}$, trombosit $215.000 / \mathrm{mm}^{3}$, gula darah puasa $79 \mathrm{mg} / \mathrm{dL}$, SGOT 29,5 U/L, SGPT 39,1 U/L, ureum 53,4 $\mathrm{mg} / \mathrm{dL}$, kreatinin $2,4 \mathrm{mg} / \mathrm{dL}$, asam urat 7,5 mg/dL, natrium $131 \mathrm{mEq} / \mathrm{L}$, kalium 3,8 mEq/L, klorida $103 \mathrm{mEq} / \mathrm{L}$. Pada pasien ini direncanakan pemasangan kateter double lumen atau arteriovenous shunt untuk akses hemodialisis, tetapi pasien masih menolak. Pada hari perawatan ke-36, pasien diperbolehkan rawat jalan tapi pasien masih menolak untuk rawat jalan. Pasien juga menolak untuk dilakukan hemodialisis walaupun telah dijelaskan segala resiko yang bisa terjadi.

\section{BAHASAN}

Pseudoaneurisma merupakan kelainan pembuluh darah yang timbul akibat gangguan pada kontinuitas dinding arteri yang disebabkan oleh peradangan, trauma, atau penyebab iatrogenik seperti prosedur bedah, biopsi per kutan, atau drainase. Insiden pseudoaneurisma yang meningkat pada praktek rumah sakit dihubungkan dengan banyaknya tindakan invasif yang dilakukan. $^{7}$ Arteri femoralis merupakan salah satu arteri yang paling sering terjadi pseudoaneurisma. ${ }^{8,11}$ PAF bisa disebabkan oleh tusukan terhadap arteri femoralis yang terlalu distal, yaitu pada percabangan arteri femoralis atau di bawahnya. PAF terbentuk ketika tusukan pada arteri gagal menutup sehinggga memungkinkan darah dari arteri terpompa ke sekeliling dinding jaringan arteri dan membentuk hematom. ${ }^{3,4,6,8}$ Pada pasien ini terbentuknya pseudoaneurisma pada arteri femoralis kiri akibat tusukan saat tindakan hemodialisis.

Pseudoaneurisma bisa asimtomatik dan terdeteksi secara kebetulan saat pemeriksaan radiologik untuk diagnosis penyakit yang lain atau pada saat operasi. ${ }^{12,13}$ Pseudoaneurisma simtomatik bermanifestasi pada gejala dan tanda lokal maupun sistemik. ${ }^{14}$ Efek lokal dari pseudoaneurisma (terinfeksi atau tidak ) terjadi sekunder terhadap massa yang terbentuk akibat struktur yang berdekatan, dimana terjadi mekanisme penyesuaian diri. Kondisi ini bisa bermanifestasi sebagai massa yang berdenyut, terdengar bruit, dan bisa dirasakan thrill pada saat palpasi. ${ }^{2-4,15}$ Pada pasien ini ditemukan suatu benjolan berukuran $6 \times 5 \mathrm{~cm}$, terdengar bruit, dan adanya nyeri tekan.

Perkembangan radiologik modern te- 
lah mempermudah mendiagnosis adanya pseudoaneurisma, yang memungkinkan deteksi dini dan intervensi terapi sebelum terjadi komplikasi yang tidak dinginkan. Angiografi konvensional merupakan acuan diagnostik standar. Selain itu terdapat pemeriksaan lain yang bisa digunakan yaitu duplex doppler ultrasonography, MR angiografi, dan CT angiografi. ${ }^{16}$

Doppler USG untuk diagnosis pseudoaneurisma memiliki sensitivitas 94\%, dan spesifitas 97\%. Pemeriksaan ini cukup mudah, hasilnya dapat langsung dilihat, tidak mahal dan cepat, serta tidak terdapat radiasi ion atau material kontras yang bisa merusak ginjal. Keterbatasan penggunaan doppler USG yaitu pada evaluasi bagian arteri yang lebih dalam atau defek intimal, terlebih bila ada hematom; dan hasil doppler USG sangat bergantung pada operator. B-mode USG memiiki keuntungan dalam pencitraan pembuluh darah ekstremitas dengan resolusi seperti angiografi biplanar. Penerapan utamanya pada pembuluh darah karotis, trombosis vena dalam, dan penyakit vaskuler yang lain, pengunaan untuk evaluasi cedera vaskuler mulai dipertimbangkan akhir-akhir ini. Keuntungannya seperti USG yang lain dan juga dapat menentukan adanya defek intimal yang tidak dapat diketahui melalui pemeriksaan fisik dan $d u$ plex doppler USG. ${ }^{17}$

CT angiografi merupakan salah satu pemeriksaan yang banyak dipilih dimana tidak hanya dapat menentukan lokasi dan morfologi pada pseudoaneurisma tapi dapat mendeteksi kerusakan-kerusakan yang lain atau penyakit-penyakit penyerta sebagai suatu kesatuan seperti pankreatitis. Hanya saja CT angiografi lebih inferior dibandingkan dengan angiografi konvensional. ${ }^{2,3,7,9,18}$

Kasus ini hanya dilakukan doppler USG dan didapatkan suatu gambaran aneurisma arteri femoralis sinistra. CT angiografi, angiografi konvensional ataupun pemeriksaan yang lain tidak dilakukan karena fasilitas tersebut belum tersedia.

Penatalaksanaan PAF berdasarkan besar kecilnya pseudoaneurisma, ada tidaknya gejala, dan letak dari arteri yang terkena. Pseudoaneurisma kecil $(<2 \mathrm{~cm})$ dapat sembuh dengan sendirinya melalui trombosis. $^{2-4,10,19}$ Umumnya PAF membutuhkan terapi intervensi. Pseudoaneurisma yang bergejala harus segera diobati untuk menghindari terjadinya ruptur. Dahulu, pembedahan dini untuk reparasi pseudoaneurisma dianjurkan. Saat ini, terapi intervensi telah dikembangkan sebagai alternatif dari tindakan pembedahan. Metode ini mempunyai tindakan invasif minimal dengan angka kesuksesan yang tinggi, komplikasi lebih sedikit serta angka kematian yang lebih kurang dibandingkan pembedahan. $^{20}$

Terapi intervensi yang terbaru termasuk kompresi dengan tuntunan USG, manajemen perkutaneus secara langsung (misalnya injeksi trombin dengan tuntunan USG) dan manajemen endovaskular (embolisasi dan implan stent-graft). Kompresi dengan tuntunan USG sangat bermanfaaat untuk pseudoaneurisma superfisial paska kateterisasi, seperti arteri femoralis dan brakhialis. Teknik ini memiliki keterbatasan, karena sangat dipengaruhi oleh kenyamanan penderita dan operatornya. Beberapa penulis menganjurkan kompresi dengan tuntunan USG ini digantikan dengan injeksi trombin dengan tuntunan USG, karena memiliki angka kesembuhan yang lebih tinggi dan membutuhkan waktu yang lebih singkat untuk penyembuhan.

Injeksi trombin ini tidak terbatas pada pseudoaneurisma arteri superfisial saja; Pseudoaneurisma yang berada pada arteri viseral yang dalam dapat juga diobati dengan metode ini, apalagi bila arteri utamanya tidak dapat dicapai. Manajemen endovaskular dilakukan untuk mengeluarkan pseudoanurisma dari sirkulasi. Metode ini dibagi dua kategori yaitu embolisasi dan penempatan stent. Pemilihan metode ini secara optimal tergantung pada ukuran dari leher pseudoaneurisma dan arteri donor yang dapat dipakai. ${ }^{2-5,12-14}$

Pembedahan pada terapi pseudoaneurisma masih memiliki peranan penting, walaupun banyak komplikasinya seperti risiko terkait anastesia, perdarahan, infeksi pada luka, waktu sembuh yang lama, dan 
juga bisa terjadi kematian. ${ }^{21}$ Pembedahan biasanya dilakukan bila telah terjadi komplikasi dari pseudoaneurisma seperti perdarahan, iskemi atau neuropati akibat efek lokal dari massa pseudoaneurisma, dan pseudoaneurisma yang telah terinfeksi. Pembedahan juga dilakukan bila tindakantindakan invasif minimal lainnya telah gagal. $^{13,14,16-18}$ Pada kasus ini dilakukan pembedahan (Gambar 3) segera karena telah terjadi ruptur dan perdarahan dari pseudoanurisma. Kompresi maupun injeksi trombin tidak dilakukan karena fasilitas tersebut belum tersedia. Setelah dilakukan operasi, pasien mengalami perbaikan dan tidak terdapat komplikasi pembedahan. Prognosis secara keseluruhan pada pasien ini dubia ad malam, tetapi untuk pseudoaneurisma prognosisnya baik.

\section{SIMPULAN}

Telah dilaporkan seorang laki-laki dengan pseudoaneurisma arteri femoralis. Diagnosis ditegakkan berdasarkan gejala dan tanda klinis dimana ditemukan benjolan di lipat paha yang timbul akibat tusukan pada saat menjalani hemodialis; pemeriksaan fisik adanya bruit pada benjolan; dan USG doppler didapatkan aneurisma arteri femoralis. Pasien dilakukan pembedahan, dan pada waktu eksplorasi ternyata benjolan tersebut merupakan suatu pseudoaneurisma arteri femoralis. Setelah perawatan hari ke-36, keadaan pasien membaik dan bisa dipulangkan. Prognosis pseudoaneurisma pada pasien ini baik tetapi secara keseluruhan dubia ad malam.

\section{DAFTAR PUSTAKA}

1. Linda JD, Patricia HF. Penyakit pembuluh darah. In: Sylvia AP, Lorraine MW, Editors. Patofisiologi Konsep Klinis Proses-Proses Penyakit, Volume 1 (Edisi Keenam). Jakarta: EGC, 2012.

2. Lenartova M, Tak $T$. Iatrogenic pseudoaneurysm of femoral: case report and literature review. Clin Med \& Research [serial online]. 2003 [cited 2012 Jul 9];1(3):243-7. Available from: doi: $10.3121 / \mathrm{cmr} \cdot 1.3 .243$.
3. Souza JD, Bedi VS, Indrasjit IK, Pant R. Non surgical management of pseudoaneurysms. MJAFI. 2007;63:115-9.

4. Saad NE, Saad WE, Davies MG, Waldman DL, Fultz PJ, Rubens DJ. Pseudoaneurysms and the role of minimally invasive techniques in their management. RadioGraphics 2005; 25 (supp 11):S173-S189.

5. Omid HF. Iatrogenic femoral artery pseudoaneurysm review of treatment options. ARYA Atherosclerosis Journal. 2010;6(2):74-7.

6. Kronzon I. Diagnosis and treatment of iatrogenic femoral artery pseudoaneurysms [homepage on the Internet]. Nodate [cited 2012 Jul 9]. Available from: http://www.ncbi.nlm.nih.gov/ pubmed/9109690.

7. Ritchie ED, Haverkamp D, Schiphorst TJMJ, Bosscha K. False aneurysm of the profunda femoris artery, a rare complication of a proximal femoral fracture. Acta Orthop. Belg. 2007; 73(4):530-2.

8. Anupong L, Yuddhasert S, Olarn A. Pseudoaneurysm of profunda femoris artery following internal fixation of intertrohanteric fracture: two cases report. J Med Assc Thai. 2005; 88(11):1703-6.

9. Chong Z, Neil EL, Roger WD. Femoral pseudoaneurysm and sudden death. J Forensic Sci. 2012;51(1):254-256.

10. Chong KC, Yap EC, Lam KS, Low BY. Profunda femoris artery pseudoaneurysm presenting with triad of thigh swelling, bleeding and anemia. Ann Acad Med Singapore. 2004;33:267-9.

11. Onder D, Talantbek B, Zulkuf E, Igor P. Femoral pseudoaneurysm due to diagnostic or interventional angiographic procedures. Angiology. 2005; 56:553-6.

12. Randall WF, Christi H. Delayed pseudoaneurysm repair: a case report. Int J Angiol. 2007; 16(3):119-20.

13. Essam B. Vascular ultrasound guided compression repair of post cardiac cathe-terization femoral artery pseudoaneurysms. Heart Mirror journal. 2009;3(1):46-52.

14. Zhu XL, Ni CF, Liu YZ, Jin YH, Zou JW, Chen L. Treatment strategies and indications for interventional mana- 
gement of pseudoaneurysms. Chin Med J. 2011;124(12):1784-9.

15. Szendro G, Golcman L, Klimov A, Yefim C, Batsheva JRVT, Avrahami E, et al. Arterial false aneurysms and their modern management. IMAJ. 2001;3:5-8.

16. Frias PA, Garcia FJG, Ortiz Gómez JA, Prieto Montaña JR, Gonzalo Vivar F. False aneurysm in an ileofemoral Dacron graft after totel hip arthroplasty. Acta Orthop. Belg. 1993;59(2):214-8.

17. Esfe ARG, Bozorg SMV, Yazdi HR. Pseudoaneurysm of a high origin radial artery treated by ultrasound-guided com-pression. Singapore Med J. 2009; 50(7): e250-e252.

18. Putterman D, Niman D, Cohen G. Aortic pseudoaneurysm after penetration by a simon nitinol inferior vena cava filter. $\mathbf{J}$ Vasc Interv Radiol. 2005;16:535-8.

19. Ashok LR, Julie AC, Muthu G, Dean TW. Missed diagnosis of ankle pseudoaneurysm following ankle arthroscopy: a case report. Cases Journal. 2009;2(162):1-4.

20. Shaw A, Stephen AB, Lund JN, Bungay P, DeNunzio M. Geniculate arterial pseudoaneurysm formation following trauma and elective orthopaedic surgery to the knee: 2 care reports and areview of the literature. Radiology Case J. 2009;3(3):12-16.

21. Agrawal GA, Johnson PT, Fishman EK. Splenic artery aneurysms and pseudoaneurysms: clinical distinction and CT appearances. AJR. 2007;188:992-9. 